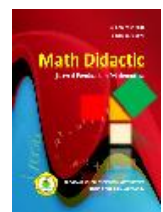

MATH DIDACTIC: JURNAL PENDIDIKAN MATEMATIKA

Volume 4 Nomor 2, Mei - Agustus 2018, halaman 146 - 154

Tersedia Daring pada http://jurnal.stkipbjm.ac.id/index.php/math

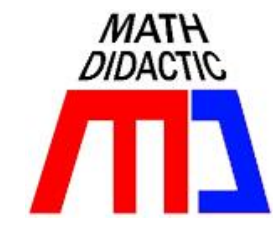

\title{
KEMAMPUAN PEMECAHAN MASALAH DALAM MENYELESAIKAN SOAL MATERI PECAHAN OLEH SISWA SMP DITINJAU DARI TAHAPAN POLYA
}

\section{CAPABILITIES OF PROBLEM SOLVING IN COMPLETING THE MATTER OF FRACTIONAL BY JUNIOR HIGH SCHOOL STUDENTS BY POLYA'S STEPS}

\author{
Januar Rahmasari Saputri, Helti Lygia Mampouw \\ Pendidikan Matematika Fakultas Keguruan dan Ilmu Pendidikan Universitas Kristen Satya Wacana Salatiga \\ 202014106@student.uksw.edu, helti.mampouw@staff.uksw.edu
}

\begin{abstract}
Abstrak: Penelitian ini bertujuan untuk mendeskripsikan kemampuan pemecahan masalah dalam menyelesaikan soal cerita materi pecahan oleh siswa SMP ditinjau tahap Polya. Jenis penelitian ini adalah penelitian deskriptif dengan pendekatan kualitatif. Subjek penelitian terdiri dari 3 siswa kelas VII SMP yakni 1 siswa berkemampuan tinggi, 1 siswa berkemampuan sedang, dan 1 siswa berkemampuan rendah. Hasil Penelitian menunjukkan bahwa: (1) Siswa berkemampuan tinggi mampu menyelesaikan permasalahan matematika materi pecahan dengan melalui semua tahap Polya. (2) Siswa berkemampuan sedang dalam menyelesaikan permasalahan matematika materi pecahan belum mampu melalui semua tahap Polya. Mereka hanya mampu melalui tahap memahami masalah. (3) Siswa berkemapuan rendah dalam menyelesaikan permasalahan matematika materi pecahan belum mampu melalui semua tahap Polya. Mereka hanya mampu melalui tahap memahami masalah dan membuat rencana.
\end{abstract}

Kata Kunci: pemecahan masalah, pecahan, polya.

Abstract: This study aims to describe the problem solving ability in solving the matter of fractional by junior high school students by Polya's step. The type of this research is descriptive research with qualitative approach. The subjects of the study consisted of 3 students of grade VII SMP namely 1 high-ability students, 1 medium-ability student, and 1 low-ability students. The results showed that: (1) High ability student were able to solving mathematical problem of fractional material by going through all stages of Polya. (2) Medium ability students to solving mathematical problems of fractional materials have not been able to go through all stages of Polya. They are only able to go through the stage of understanding the problem. (3) Low ability student to solving mathematical problems of fractional materials have not been able to go through all stages of Polya. They are only able to go through the stage of understanding the problem and making plans.

Keywords: problem solving, fractional, polya

Cara Sitasi: Saputri, J.R., \& Mampouw, H.L. (2018). Kemampuan pemecahan masalah dalam menyelesaikan soal materi pecahan oleh siswa SMP ditinjau dari tahapan Polya. Math Didactic: Jurnal Pendidikan Matematika, 4(2), $146-154$.

Matematika menjadi salah satu pelajaran yang diberikan pada tingkat sekolah dasar sampai lanjutan atas dengan tujuan untuk membantu melatih pola pikir siswa agar dapat memecahkan masalah. Pernyataan ini sesuai dengan PERMENDIKNAS No. 22 Tahun 2006, mata pelajaran matematika salah satunya bertujuan agar peserta didik memiliki kemampuan memecahkan masalah yang meliputi kemampuan memahami masalah, merancang model matematika, menyelesaikan model dan menafsirkan solusi yang diperoleh. Hudojo dalam Indarwati, (2014, hal. 19) menyatakan bahwa pemecahan masalah 
merupakan proses yang ditempuh seseorang untuk menyelesaikan masalah yang dihadapinya. Siswa dituntut untuk menggunakan segala pengetahuan yang diperolehnya untuk dapat memecahkan suatu masalah matematika (Ambarwati, 2016, hal. 239). Silver dalam Singer (2011, hal. 1134) mengemukakan bahwa pembelajaran matematika yang mencakup pemecahan masalah dan tugas dapat membantu siswa untuk mengembangkan lebih kreatif dalam bidang matematika. Berdasarkan uraian tersebut maka kemampuan siswa dalam pemecahan masalah khususnya pada mata pelajaran mateamtika perlu ditekankan agar dapat membantu siswa mengembangkan aspek-aspek penting dalam matematika seperti penerapan aturan pada penemuan pola, penggeneralisasian, dan komunikasi matematika.

Pecahan merupakan materi pokok matematika dalam kurikulum pendidikan yang diajarkan pada siswa kelas VII SMP. Pada pokok bahasan pecahan mempelajari konsep operasi pecahan pada soal cerita. Soal cerita matematika merupakan salah satu bentuk soal matematika yang memuat aspek kemampuan untuk membaca, menalar, menganalisis serta mencari solusi, untuk itu siswa dituntut dapat menguasai kemampuan-kemampuan dalam menyelesaikan soal cerita matematika tersebut. (Wahyudi dan Ihsan, 2016, hal. 111). Umam (2014, hal. 132) menambahkan bahwa soal cerita dalam matematika terdapat banyak aspek penyelesaian masalah dan dalam menyelesaiakannya siswa harus mampu memahami maksud dan permasalahan yang akan diselesaikan, dapat menyusun model matematikanya serta mampu mengaitkan permasalahan tersebut dengan materi pembelajaran yang telah dipelajari sehingga dapat menyelesaiakannya dengan menggunakan pengetahuan yang telah dimiliki.

Berdasarkan teori perkembangan kognitif oleh Piaget, siswa SMP kelas VII pada umunya berusia antara 11-14 tahun dan berada pada tahap operasi formal awal. Santrock (2009, hal. 57-59) menyatakan bahwa pada tahap ini individu dapat mengambil keputusan berdasarkan pengalaman nyata, dapat mengidealisasikan dan memperkirakan berbagai kemungkinan sehingga dapat berpikir logis untuk menyusun rencana dalam memecahkan masalah. Namun keadaan di lapangan bertolak belakang dengan teori Piaget. Siswa masih mengalami kesulitan dalam memecahkan masalah, dalam hal ini masalah yang dimaksud adalah masalah soal cerita matematika yang berkaitan dengan kehidupan sehari-hari. Penelitian Ningrum (2013) menyatakan bahwa siswa mengalami kesulitan dalam menyelesaikan soal matematika dalam bentuk cerita, memahami bahasa, apa yang ditanyakan dalam soal, dan dalam perhitungan. Pendapat ini diperkuat oleh Nurmalasari (2016) yang pada penelitiannya menjelaskan bahwa siswa kurang memahami konsep soal dan masih sulit memahami setiap kalimat soal cerita yang berkaitan dengan dunia nyata pada materi pecahan. Siswa hanya berfokus pada cara menyelesaikan soal tanpa memperdulikan langkah-langkah yang tepat untuk menyelesaikan permasalahan tersebut.

Beberapa ahli menemukan langkahlangkah dalam memecahkan masalah, salah satunya ialah langkah-langkah pemecahan masalah yang dikemukakan oleh Krulik dan Rudnick (1995, hal. 6-7) yang menyatakan ada lima tahapan yaitu; membaca, memeriksa, memilih strategi, memecahkan masalah, dan langkah terakhir adalah meninjau dan memperluas. Selain itu, Polya menemukan 
langkah-langkah praktis dan tersusun secara secara sistematis dalam memecahkan masalah sehingga dapat memudahkan siswa dalam menyelesaikan masalah matematika. Polya (1973, hal. 5-22) menetapkan empat langkah dalam menyelesaikan suatu masalah matematika, yaitu: Understanding the problem, devising a plan, carrying out the plan dan looking back. Pada penelitian ini mengunakan langkah-langkah Polya yang digunakan dalam menyelesaiakan masalah. Langkah Polya tersebut menyediakan kerangka kerja yang tersusun rapi sehingga dapat membantu siswa dalam menyelesaikan soal cerita khususnya matematika. Adapun penjabaran dari keempat langkah-langkah Polya yang digunakan sebagai landasan dalam memecahkan masalah adalah sebagai berikut:

1) Pemahaman Masalah (Understanding the problem).

Siswa harus dapat memahami kondisi soal atau masalah yang ada pada soal tersebut. Sasaran penilaian pada tahap ini meliputi:

a. Siswa mampu menganalisis soal. Hal ini dapat dilihat apakah siswa tersebut paham dan mengerti terhadap apa yang diketahui dan yang ditanyakan dalam soal.

b. Siswa mampu menuliskan apa yang diketahui dan apa yang ditanyakan dalam bentuk rumus, simbol, atau kata-kata sederhana.

2) Perencanaan penyelesaian (Devising a plan)

Siswa harus dapat memikirkan langkah-langkah apa saja yang penting dan saling menunjang untuk dapat smemecahkan masalah yang dihadapinya. Pada tahap ini yang harus dilakukan siswa adalah:

a. Siswa dapat mencari konsep-konsep atau teori-teori yang saling menunjang.

b. Siswa dapat mencari rumus yang diperlukan.
3) Pelaksanaan rencana (Carrying out the plan)

Siswa harus dapat membentuk sistematika soal yang lebih baku, dalam arti rumus-rumus yang akan digunakan sesuai dengan yang dibutuhkan pada soal., kemudian siswa mulai memasukkan data hingga menjurus ke rencana pemecahan, dan melaksanakan langkah-langkah rencana sehingga diharapkan soal dapat dibuktikan atau diselesaikan.

4) Peninjauan kembali (Looking back)

Siswa harus meninjau atau memeriksa kembali langkah pemecahan masalah yang digunakan. Pada tahap ini siswa mengecek kebenaran dari hasil perhitungan yang telah dikerjakan, serta mengecek sistematika dan tahap-tahap penyelesaiannya apakah sudah benar atau belum.

Berdasarkan uraian diatas, maka dilakukan penelitian yang bertujuan untuk mendeskripsikan proses pemecahan masalah dalam menyelesaikan soal materi pecahan oleh siswa SMP ditinjau dari tahapan Polya.

\section{Metode Penelitian}

Jenis penelitian ini adalah penelitian kualitatif. Penelitian ini dilaksanakan di SMP Negeri 3 Pabelan semester genap tahun pelajaran 2017/2018. Subjek dalam penelitian ini terdiri dari 3 siswa yang memiliki kriteria yaitu siswa berkemampuan tinggi, sedang, dan rendah. Subjek penelitian diperoleh dari nilai UAS kelas VII. Pada penelitian ini siswa berkemampuan tinggi merupakan siswa dengan rentang nilai antara 86-100, siswa berkemampuan sedang dengan rentang nilai 75-85, sedangkan siswa berkemampuan rendah dengan rentang nilai 64-74. Tiga subjek dari masing-masing kategori kemampuan matematika dengan mempertimbangkan saran 
dari guru matematika kelas VII untuk memilih siswa yang dapat berkomunikasi dengan baik guna melakukan wawancara dengan kriteria dapat dilihat pada tabel 1 .

Tabel 1. Pemilihan Subjek Berdasarkan Hasil UAS

\begin{tabular}{ccc}
\hline Inisial Subjek & Nilai UAS & $\begin{array}{c}\text { Kategori } \\
\text { Kemampuan }\end{array}$ \\
\hline ST & 90 & Tinggi \\
SR & 77 & Sedang \\
SR & 73 & Rendah \\
\hline
\end{tabular}

Data dikumpulkan melalui tes tertulis dan wawancara. Data yang dianalisis adalah hasil dari soal yang dikerjakan siswa dan hasil wawancara siswa. Triangulasi teknik digunakan untuk mendapatkan data yang valid, yakni dengan mengecek data kepada sumber yang sama dengan teknik yang berbeda. Wawancara dilakukan minimal satu kali untuk setiap satu soal tes sehingga dapat diketahui tingkat kemampuan subjek dalam menyelesaikan soal cerita. Tes yang diujikan berbentuk uraian yang bertujuan untuk mengetahui setiap langkah dan alasan siswa dalam menyelesaikan soal pecahan, dengan menggunakan instrumen tes yang sudah divalidasi oleh validator. Setiap subjek diberikan 4 soal yang berisikan materi pecahan. Adapun indikator tahap Polya yang digunakan untuk mendeskripsikan ketiga subjek dapat dilihat pada tabel 2.

Tabel 2. Indikator Pemecahan Masalah Polya

\begin{tabular}{|c|c|c|}
\hline $\begin{array}{c}\text { Langkah- } \\
\text { langkah } \\
\text { Pemecahan } \\
\text { Masalah Polya }\end{array}$ & $\begin{array}{l}\text { Poin- } \\
\text { poin }\end{array}$ & Indikator \\
\hline $\begin{array}{l}\text { Pemahaman } \\
\text { Masalah } \\
\text { (Understanding } \\
\text { The Problem) }\end{array}$ & $\begin{array}{l}\text { 1. Cara siswa } \\
\text { dalam } \\
\text { menerima } \\
\text { informasi } \\
\text { yang ada } \\
\text { pada soal } \\
\text { menyebutka }\end{array}$ & $\begin{array}{l}\text { 1. Siswa dapat } \\
\text { menceritakan } \\
\text { kembali apa } \\
\text { yang } \\
\text { dipahami dari } \\
\text { soal tersebut } \\
\text { menggunaka }\end{array}$ \\
\hline & $\begin{array}{l}\mathrm{n} \quad \text { atau } \\
\text { menuliskan }\end{array}$ & $\begin{array}{l}\mathrm{n} \text { bahasa } \\
\text { sendiri. }\end{array}$ \\
\hline
\end{tabular}

hal-hal yang 2. Siswa diketahui dan ditanyakan.

2.Cara siswa dalam memilah informasi penting dan tidak penting.

1. Cara siswa dalam mengetahui keterkaitan antar informasi yang ada.

2. Cara siswa dalam memeriksa apakah semua informasi penting telah digunakan
Pelaksanaan Rencana (Carrying Out a Plan)

eninjauan Kembali (Looking Back)
1. Siswa dapat membuat langkahlangkah pemecahan secara benar.

2. Cara siswa memeriksa setiap langkah penyelesaian

Cara siswa 1. Siswa melihat untuk kembali hasil mengerjakan soal kembali dengan cara yang berbeda. dalam menulis

kembali informasi

yang diperlukan pada soal.

3. Memahami apa yang ditanyakan.

Siswa dapat membuat

rencana penyelesaian masalah berdasarkan yang ditanyakan pada soal.
1. Siswa dapat mengerjakan soal sesuai rencana yang sudah dibuat.

2. Siswa dapat memecahkan masalah yang digunakan dengan hasil yang benar. jawabannya.

2. Konsisten dalam menyimpulka $\mathrm{n}$ hasil jawaban.

\section{Hasil Penelitian dan Pembahasan}

\section{Hasil}

Hasil penelitian berupa deskripsi pekerjaan subjek penelitian berdasarkan 
jawaban dari soal pemecahan masalah pecahan secara tertulis maupun jawaban subjek ketika wawancara ditinjau dari tahapan Polya. Berikut merupakan deskripsi jawaban dari masing-masing subjek.

\section{Subjek Berkemampuan Tinggi}

Hasil analisis subjek berkemampuan tinggi dalam memecahkan masalah materi pecahan disajikan sebagai berikut.

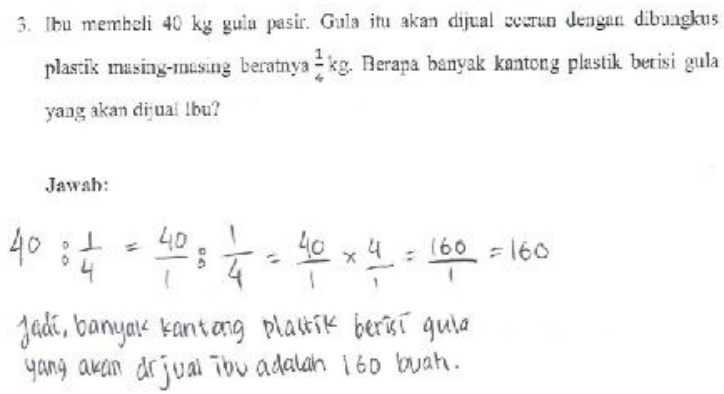

Gambar 1. Jawaban subjek berkemampuan tinggi dalam soal nomor 3

Dari penyelesaian soal tersebut diketahui bahwa ST dalam mengerjakan soal secara langsung. Hal ini terulang ketika ST mengerjakan tiga soal yang lain.

Tahap pertama pemecahan masalah pada tahap Polya yaitu mengenali masalah. ST mampu menyebutkan semua informasi yang diberikan dari pertanyaan dengan baik meskipun tidak menuliskannya apa yang diketahui dan ditanyakan pada lembar jawab. Pada tahap membuat rencana, ST juga tidak menuliskannya pada lembar jawab namun dapat menceritakan rencana penyelesaian masalah berdasarkan soal dengan benar. Berikut penggalan wawancara yang dilakukan oleh peneliti kepada ST.

$\begin{array}{ll}\text { Peneliti } & \text { : "Coba ceritakan } \\ & \text { kembali apa yang kamu } \\ & \text { pahami dari soal } \\ & \text { tersebut?" } \\ \text { ST } & \text { : "Ibu membeli } 40 \mathrm{~kg} \\ & \text { gula pasir. Gula itu akan } \\ & \text { dijual eceran dengan }\end{array}$

dibungkus plastik masing-masing beratnya $\frac{1}{4} \mathrm{~kg}$. Berapa banyak kantong plastik berisi gula yang akan dijual Ibu?"

Peneliti : "Apa yang diketahui dari soal tersebut?"

ST

: "40 kg gula pasir, yang dijual masingmasing $\frac{1}{4} \mathrm{~kg} . "$

Peneliti : "Apa yang ditanyakan dari soal tersebut?"

ST : :Banyak kantong plastik yang dijual?"

Peneliti : "Bagaimana cara mencarinya?"

ST : "40 dibagi $\frac{1}{4}$ ",

Berdarkan penggalan wawancara tersebut dapat dikatakan bahwa ST dapat mencapai indikator pada tahap mrencanakan penyelesaian masalah. Tahap menjalankan rencana, ST mengerjakan soal sesuai dengan rencana yang sudah dibuat sebelumnya serta menuliskan langkah-langkahnya dengan benar dan tepat sehingga menghasilkan jawaban yang benar. Tahap memeriksa kembali, ST mampu mengecek kembali hasilnya dan konsisten dalam menyimpulkan jawaban. Dengan demikian dapat dikatakan ST melalui semua tahapan Polya dalam menyelesaikan masalah matematika.

\section{Subjek Berkemampuan Sedang}

Hasil analisis subjek berkemampuan sedang dalam memecahkan masalah materi pecahan disajikan sebagai berikut. 


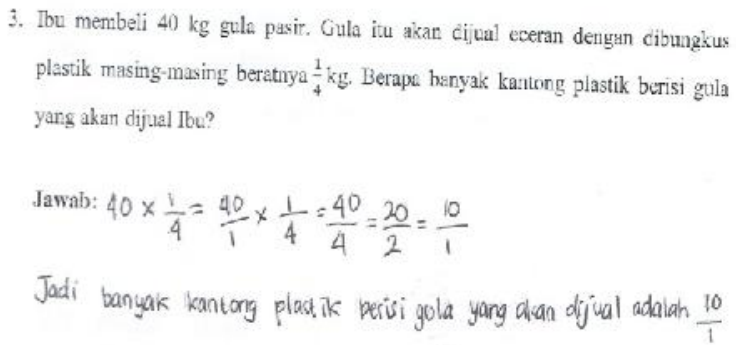

Gambar 2. Jawaban subjek berkemampuan sedang dalam soal nomor 3

Hampir sama dengan ST, SS mengerjakan soal secara langsung. Hal ini terulang ketika SS mengerjakan tiga soal yang lain. Pada tahap pertama yaitu mengenali masalah, SS mampu menyebutkan semua informasi yang diberikan dari pertanyaan dengan baik melalui wawancara meskipun tidak menuliskannya pada lembar jawab.

Berikut penggalan wawancara yang dilakukan oleh peneliti kepada SS.

Peneliti

"Coba ceritakan kembali apa yang kamu pahami dari soal tersebut?"

SS

: "Ibu membeli $40 \mathrm{~kg}$ gula pasir. Gula itu akan dijual eceran dengan dibungkus plastik masing-masing beratnya $\frac{1}{4} \mathrm{~kg}$. Berapa banyak kantong plastik berisi gula yang akan dijual Ibu?"

Peneliti : "Apa yang diketahui dari soal tersebut?"

SS : "40 kg gula dijual $\frac{1}{4} \mathrm{~kg}$ gula"

Peneliti : "Apa yang ditanyakan dari soal tersebut?"

SS
: "Banyak kantong plastik yang dijual?"

Peneliti "Bagaimana cara
mencarinya?"

SS : "40 dikali $\frac{1}{4}$,

Berdasarkan wawancara diatas diketahui bahwa SS tidak tepat dalam membuat rencana penyelesaian masalah, khusunya pada operasi pembagian pecahan. SS belum mampu mengubah persoalan nyata kedalam bentuk matematika. Hal ini mengakibatkan bahwa SS tidak dapat memenuhi indikator pada tahap membuat rencana. SS tidak tepat dalam menjalankan rencana sehingga menghasilkan jawaban yang tidak tepat. Tahap terakhir yaitu pemeriksaan kembali, SS tidak dapat mengerjakan kembali soal dengan cara yang berbeda sehingga menyimpulkan hasil jawaban yang tidak tepat. Dengan demikian SS hanya mampu melalui tahap memahami masalah dalam memecahkan masalah matematika khususnya pada operasi pembagian pecahan berdasarkan tahapan Polya.

\section{Subjek Berkemampuan Rendah}

Hasil analisis subjek berkemampuan rendah dalam memecahkan masalah materi pecahan disajikan sebagai berikut.

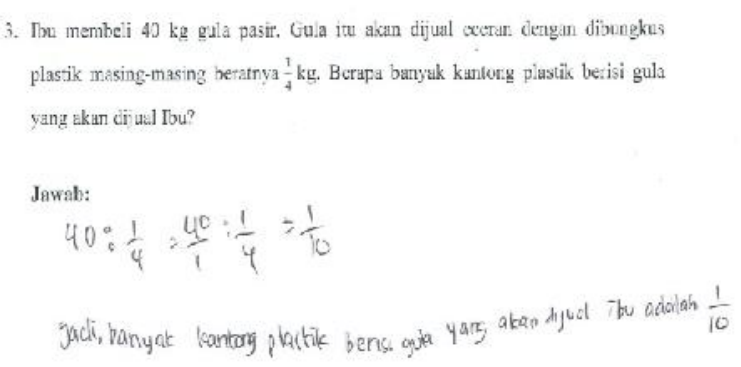

Gambar 3. Jawaban subjek berkemampuan rendah dalam soal nomor 3

Hampir sama dengan ST dan SS, SR dalam mengerjakan soal secara langsung. Hal ini terulang ketika SS mengerjakan tiga soal yang lain. Pada tahap memahami masalah, SR mampu menyebutkan apa yang diketahui namun tidak menuliskannya pada lembar jawab. Pada tahapan membuat rencana, SR 
tidak menuliskannya pada lembar jawab namun ketika diwawancarai mampu menceritakan apa yang akan ia lakukan untuk menyelesaikan masalah. Berikut penggalan wawancara yang dilakukan oleh peneliti kepada SR.

Peneliti

SR

berisi gula yang akan
dijual Ibu?"

Peneliti : “Apa yang diketahui dari soal itu?"

SR

Peneliti

SR

Peneliti

SR : "40 kg gula dan dijual eceran dengan dibungkus plastik masing-masing beratnya $\frac{1}{4} \mathrm{~kg}$."

: "Apa yang ditanyakan dari soal tersebut?"

: "Banyak kantong plastik yang dijual?"

: "Bagaimana cara mencarinya?"

: "40 dibagi $\frac{1}{4}$ ",

SR mampu membuat rencana sesuai dengan soal, hal ini menunjukan bahhwa SR mampu mencapai indikator pada tahap pembuatan rencana. Selanjutnya ialah tahap menjalankan rencana penyelesaian masalah, SR tidak dapat mengerjakan soal sesuai rencana sehingga menghasilkan jawaban yang tidak tepat. Kesulitan dalam mengoperasikan pecahan menjadi penyebab siswa berkemampuan rendah tidak dapat memenuhi indikator pada tahap melaksanakan rencana. Tahap terakhir dalam pemecahan masalah polya ialah mengecek kembali jawaban. Pada tahap ini, SR tidak dapat mengerjakan kembali soal dengan cara yang berbeda sehingga menyimpulkan hasil jawaban yang tidak tepat. Dengan demikian SR hanya dapat melalui tahap memahami masalah dan membuat rencana dalam memecahkan masalah berdasarkan tahapan Polya.

\section{Pembahasan}

\section{Subjek Berkemampuan Tinggi}

Siswa berkemampuan tinggi mampu menganalisis dan membentuk sebuah permasalahan kedalam bentuk matematika. Siswa yang tidak menuliskan apa yang ia pahami dari soal dan rencana penyelesaian masalah bukan berarti tidak bisa mengerjakannya, hanya saja mereka tidak ingin menduakalikan pekerjaan dan ingin mempersingkat waktu. Hasil analisis tersebut sejalan dengan hasil penelitian Nurmalasari (2016) yang menyatakan bahwa siswa yang memiliki kemampuan tingkat berfikir tinggi dalam menyelesaikan permasalahan yang diberikan lebih memilih menggunakan tahapan pemecahan masalah polya. Meskipun ada beberapa langkah dari tahapan polya yang tidak dituliskan, mereka tetap mampu menyelesaikan permasalahan dengan tepat. Hal ini dikarenakan mereka tidak ingin menuliskan cara pengerjaannya dua kali.

\section{Subjek Berkemampuan Sedang}

Nurmalasari (2016) dalam penelitiannya menyatakan bahwa siswa yang memiliki kemampuan tingkat berfikir sedang lebih baik dari pada siswa yang memiliki kemampuan tingkat berfikir rendah dalam memecahkan masalah. Dalam penelitiannya 
juga menemukan bahwa siswa berkemampuan sedang memiliki tingkat kemampuan operasi hitung siswa sudah sangat baik. Namun hal ini berbeda dengan apa yang peneliti temukan. Dalam penelitian ini ditemukan bahwa siswa berkemampuan sedang dan rendah memiliki kesamaan yaitu kurang tepat pada tahap pelaksanaan rencana sehingga menghasilkan jawaban tidak tepat. Justru ditemukan bahwa siswa berkemampuan rendah lebih baik pada tahap perencanaan cara penyelesaian dalam memecahkan masalah. Siswa berkemampuan sedang masih kesulitan dalam memahami dan menganalisis permasalahan sehingga membuat mereka kesulitan mengubah permasalahan kedalam bentuk matematika dan penyelesaiannya. Selain itu siswa berkemampuan sedang masih kesulitan dalam mengoperasikan bentuk pecahan.

\section{Subjek Berkemampuan Rendah}

Siswa berkemampuan rendah mampu mencapai tahap membuat rencana dalam memecahkan masalah Polya. Hal ini membuktikan bahwa siswa berkemampuan rendah lebih baik daripada siswa berkemampuan sedang yang hanya mencapai pada tahap memahami rencana dalam menyelesaikan masalah. Siswa berkemampuan rendah masih kesulitan dalam mngoperasikan bilangan pecahan. Hasil penelitian ini bertolak belakang dari hasil penelitian Nurmalasari (2016) yang menyatakan bahwa siswa yang memiliki kemampuan tingkat berfikir rendah belum memahami permasalahan dan belum mampu mengubah suatu masalah kedalam bentuk matematika lebih cenderung mengoperasikan semua angka yang telah ada dalam permasalahan.

\section{Simpulan dan Saran}

\section{Simpulan}

Siswa berkemampuan tinggi dalam menyelesaikan masalah mampu melalui semua tahapan pemecahan masalah Polya. Mereka tetap mampu menyelesaikan permasalahan dengan tepat, memiliki kemampuan operasi hitung siswa sudah sangat baik. Siswa yang tidak menuliskan apa yang ia pahami dari soal dan rencana penyelesaian masalah bukan berarti tidak bisa mengerjakannya, hanya saja mereka tidak ingin menduakalikan pekerjaan dan ingin mempersingkat waktu. Siswa berkemampuan sedang dalam menyelesaikan masalah, belum mampu melalui semua tahapan pemecahan masalah Polya, hanya dapat melalui tahap memahami masalah dan membuat rencana. Mereka belum memahami permasalahan dan belum mampu mengubah suatu masalah kedalam bentuk matematika dan masih kesulitan dalam mengoperasikan bentuk pecahan. Siswa berkemapuan rendah dalam menyelesaikan masalah belum mampu melalui semua tahapan pemecahan masalah Polya, hanya dapat melalui tahap memahami masalah dan membuat rencana. Siswa berkemampuan rendah masih kesulitan dalam mngoperasikan bilangan pecahan.

\section{Saran}

Setiap siswa memiliki kemapuan pemecahan masalah yang berbeda. Perbedaan tersebut dapat terlihat pada setiap tahapan pemecahan masalah matematika berdasarkan tahapan Polya. Kemampuan pemecahan masalah ini dapat ditingkatkan dengan latihanlatihan soal berbasis masalah sehingga menuntut siswa untuk lebih memahami dalam memecahkan suatu permasalahan. Dengan mengetahui kemampuan pemecahan masalah 
setiap siswa berbeda dapat mempermudah guru dalam menentukan strategi dan metode yang efektif dalam pembelajaran.

Saran dapat berupa masukan bagi peneliti berikutnya, dapat pula rekomendasi implikatif dari temuan penelitian.

\section{Daftar Pustaka}

Ambarwati, Mika. 2016. Analisis Kemampuan Pemecahan Masalah Dalam Strategi Think Talk Write (Ttw). terdapat di: ojs.umsida.ac.id/index.php/pedagogia/art icle/view/256.diunduh pada hari Jum' at 31 Maret pukul 11.42 WIB

Indarwati, Desi. (2014). Peningkatan Kemampuan Pemecahan Masalah Matematika Melalui Penerapan Problem Based Learning Untuk Siswa Kelas V SD. Terdapat Di http://Ejournal.Uksw.Edu/Satyawidya/Ar ticle/View/107/95. Di Unduh Pada Hari Rabu 10 Mei 2017 pukul 18.16 WIB

Krulik, Stepehen and Rudnick. 1995. The New Soucebok for Teaching Reasoning and Problem Solving in Elementary School.

Ningrum, Lilis. 2013. Analisis Kemampuan Siswa Menyelesaikan Soalmatematika Dalam Bentuk Cerita Pokok Bahasanbarisan Dan Deret Pada Siswa Kelas Xii SMA Al-Islam 3 Surakarta. terdapat di: eprints.ums.ac.id/23172/19/NASKAH_P UBLIKASI.pdf diunduh pada hari Jum'at 14 April 2017 pukul 10.30 WIB.

Nurmalasari, Widyastuti. 2016. Analisis Pemecahan Masalah Dalam Penyelesaian Soal Pecahan Kelas Vii Smp Muhammadiyah 1 Surakarta Tahun
2015/2016. Terdapat di: eprints.ums.ac.id/44807/ diunduh pada hari Jum'at 14 April 2017 pukul 10.30 WIB

Polya, G. 1973. How To Solve It. (A new Aspect of Mathematical Method). Stanford University. Garden City, New York.

Shantrock, Jhon. 2009. Psikologi Pendidikan. Jakarta: Salemba Humanika.

Singer, F. M., Pelczer, I., Voica, C. (2011). Problem posing and modification as a criterion of mathematical creativity. terdapat https://www.researchgate.net/publication/ 266870929_PROBLEM_POSING_AND _MODIFICATION_AS_A_CRITERION _OF_MATHEMATICAL_CREATIVIT

Y diunduh pada hari Kamis 13 April 2017 pukul 19.00 WIB

Umam, Muhammad. 2014. Analisis Kesalahan Siswa Dalam Menyelesaikan Soal Cerita Matematikamateri Operasi Hitung Pecahan. terdapat di: jurnalmahasiswa.unesa.ac.id/index.php/ mathedunesa/ diunduh pada hari Jum'at 14 April 2017 pukul 10.30 WIB

Wahyuddin dan Ihsan, Muhammad. Analisis Kemampuan Menyelesaikan Soal Cerita Matematika Ditinjau dari Kemampuan Verbal pada Siswa Kelas VII SMP Muhammadiyah Se-Kota Makasar. Terdapat di: ejournal.uinsuska.ac.id/index.php/SJME/article/view/ 2213. diunduh pada hari Jum'at 14 April 2017 pukul 10.30 WIB 